\title{
SMART CHARGING DIGITAL ACCUMULATOR BASED ON ARDUINO UNO MICROCONTROLLER
}

\author{
Winarno Fadjar Bastari*, Aris Prayogi \\ Department of Electrical Engineering \\ University of PGRI Adi Buana Surabaya \\ *Corresponding email address: winarnofbastari@unipasby.ac.id
}

\begin{abstract}
The charging device usually uses a transformer and a diode bridge. Charging the battery is called direct charging. Because it does not have a safety for the battery it can cause heat to the battery. But over time, this is no longer effective, this work can be done digitally using a microcontroller. However, this tool is still not perfect because at the time of testing it cannot be set, sooner or later, the charging is to cut time efficiency and there is no indicator that states that the charging is full or not. Therefore, based on the description above, the researcher aims to make a smart charging accumulator based on the Arduino Uno microcotroller that is smarter, more efficient and can be used easily, with the advantage of having a tap changer on the transformer that functions as a regulator of the output voltage. as desired and piezoelectric alarm as an indicator if a full charge or there is a problem with the equipment itself.
\end{abstract}

Keywords: Arduino Uno, Diode Bridge, Current Sensor, Transformer

\section{INTRODUCTION}

The battery is one of the energy storage which is very widely used by the community. The charging device usually only uses a transformer and a diode bridge, charging this kind of battery is called direct charging. But along with the times, this thing is no longer effective. Now this work can be done digitally using a microcontroller. Microcontroller is a complete microprocessor in one chip. The microcontroller system has a higher level of accuracy when compared to humans. (Kadir: 2014).

In Mubaraq's research (2017), on a microcotrollerbased battery charging device that functions as a protection regulator when charging the battery, it states that there are current and voltage sensors that measure the current and voltage entering the battery. In addition to current and voltage sensors, the author uses a relay as a charging breaker on the battery. If the battery is full and read by the sensor, the Relay will cut off the charging process.

However, the device is felt to be still incomplete because during charging, fast or slow charging settings cannot be made for time efficiency, and there is no alarm indicator that can indicate that the accumulator is full or if there is a problem with the charging device itself..

Based on the above considerations, the researcher aims to make a smart charging accumulator based on the Arduino Uno microcontroller that is smarter, more efficient and can be used easily. This tool has several advantages, namely that it can be operated automatically or manually, then with the tap changer on the transformer that can be controlled via a rotary switch and Arduino Uno. The tap charger function is to speed up or slow down battery charging according to user needs. Furthermore, with the presence of an alarm instrument and an LCD, the alarm will sound a signal and the LCD will display a layout that informs the operator that charging the battery is complete or if the charging device is damaged.

\section{RESEARCH METHODS}

To support this research, the authors make an arrangement of product research designs that will assist in the process of making, testing and collecting the necessary data.

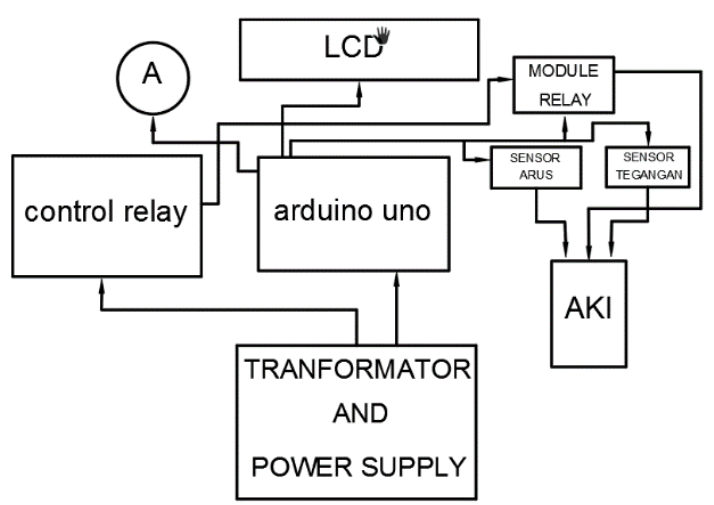

Figure 1 Block diagram of product design

2.1 The description of the tool image is as follows:

a. Arduino Uno in the block diagram as a microcontroller which functions to manage data and execute data.

b. The power supply in the block diagram is a source of $220 \mathrm{~V}$ AC input voltage. 
BEST

Journal of Applied Electrical \& Science Technology - University of PGRI Adi Buana

p-ISSN 2715-2871

e-ISSN 2714-5247

c. The transformer in the block diagram functions as a step down to reduce the voltage from $220 \mathrm{~V}$ to $13.9 \mathrm{~V}, 14.7 \mathrm{~V}, 15 \mathrm{~V}, 15.9 \mathrm{~V}, 18.4 \mathrm{~V}, 20.3 \mathrm{~V}$ and $22 \mathrm{~V}$ AC.

d. The control relay in the block diagram functions as an automatic control for the output of the transformer.

c. The current sensor in the block diagram serves as a reading of the current flowing in the accumulator load.

f. The voltage sensor in the block diagram functions as a voltage reading at the start of charging and completion of charging.

g. The relay module in the block diagram functions as an automatic breaker in case of an over current or a problem during charging.

h. The alarm on the block diagram functions as an indicator if the charging is full or there is a problem with the charging device

i. The LCD in the block diagram functions as a data reading for voltage, current and if there is a problem with the charging device.

j. The battery in the block diagram functions as a charging output

\subsection{Data Analysis Techniques}

The data analysis used is experimental data analysis to analyze the accuracy of the tool through the right components after testing:

a. Transformer testing

In this test, it is carried out by testing the megger and the output of the transformer with a voltage input of $220 \mathrm{~V}$. The results are presented in table 1 as follows :

Tabel 1 Transformator Testing

\begin{tabular}{|c|c|c|}
\hline NO & TIME & CURRENT \\
\hline 1 & $\begin{array}{c}\text { Megger primer } \\
\text { dan sekunder }\end{array}$ & 20000M $\Omega$ \\
\hline 2 & Tap 1 & $12,70 \mathrm{~V}$ \\
\hline 3 & Tap 2 & $13,88 \mathrm{~V}$ \\
\hline 4 & Tap 3 & $14,27 \mathrm{~V}$ \\
\hline 5 & Tap 4 & $15,14 \mathrm{~V}$ \\
\hline 6 & Tap 5 & $17,20 \mathrm{~V}$ \\
7 & Tap 6 & $19,62 \mathrm{~V}$ \\
\hline
\end{tabular}

\section{b. Voltage Variation}

The voltage variation test is a test carried out on the transformer output. The voltage variation was carried out on the transformer with an initial voltage of $10 \mathrm{~V}$ and then a charging voltage of $12.70 \mathrm{~V}$; $13.88 \mathrm{~V} ; 14.27 \mathrm{~V} ; 15.14 \mathrm{~V} ; 17.20 \mathrm{~V}$; and 19.62V DC and gives the same length of time. The following are the results obtained.

1. Voltage variation $12.70 \mathrm{~V}$

In the first experiment with a voltage variation of $12.70 \mathrm{~V}$, the results are presented in table 2 as follows :

Tabel 2 Voltage variation 12,70 V
\begin{tabular}{|c|c|c|}
\hline NO & TIME & CURRENT \\
\hline 1 & 10 menit & $0,51 \mathrm{~A}$ \\
\hline 2 & 20 menit & $0,52 \mathrm{~A}$ \\
\hline 3 & 30 menit & $0,49 \mathrm{~A}$ \\
\hline 4 & 40 menit & $0,41 \mathrm{~A}$ \\
\hline 5 & 50 menit & $0,51 \mathrm{~A}$ \\
\hline
\end{tabular}

2. Voltage variation $13.88 \mathrm{~V}$

In the second experiment with a voltage variation of $13.88 \mathrm{~V}$, the results are presented in table 3 as follows :

\section{Tabel 3 Voltage variation $13,88 \mathrm{~V}$}

\begin{tabular}{|c|c|c|}
\hline NO & TIME & CURRENT \\
\hline 1 & 10 menit & $1,11 \mathrm{~A}$ \\
\hline 2 & 20 menit & $1,14 \mathrm{~A}$ \\
\hline 3 & 30 menit & $0,91 \mathrm{~A}$ \\
\hline 4 & 40 menit & $0,89 \mathrm{~A}$ \\
\hline 5 & 50 menit & $0,77 \mathrm{~A}$ \\
\hline
\end{tabular}

3. Voltage variation $14.27 \mathrm{~V}$

In the third experiment with a voltage variation of $14.27 \mathrm{~V}$, the results are presented in table 4 as follows :

Tabel 4 Voltage variation $14,27 \mathrm{~V}$

\begin{tabular}{|c|c|c|}
\hline NO & TIME & CURRENT \\
\hline 1 & 10 menit & $1,49 \mathrm{~A}$ \\
\hline 2 & 20 menit & $1,71 \mathrm{~A}$ \\
\hline 3 & 30 menit & $1,51 \mathrm{~A}$ \\
\hline 4 & 40 menit & $1,39 \mathrm{~A}$ \\
\hline 5 & 50 menit & $1,29 \mathrm{~A}$ \\
\hline
\end{tabular}

\section{Voltage variation $15.14 \mathrm{~V}$}

In the fourth experiment with a voltage variation of $15.14 \mathrm{~V}$, the results are presented in table 5 as follows : 
Tabel 5 Voltage variation $15,14 \mathrm{~V}$

\begin{tabular}{|c|c|c|}
\hline NO & TIME & CURRENT \\
\hline 1 & 10 menit & $1,49 \mathrm{~A}$ \\
\hline 2 & 20 menit & $1,71 \mathrm{~A}$ \\
\hline 3 & 30 menit & $1,51 \mathrm{~A}$ \\
\hline 4 & 40 menit & $1,39 \mathrm{~A}$ \\
\hline 5 & 50 menit & $1,29 \mathrm{~A}$ \\
\hline
\end{tabular}

5. Voltage variation $17.20 \mathrm{~V}$

In the fifth experiment with a voltage variation of $17.20 \mathrm{~V}$, the results are presented in table 6 as follows :

Tabel 6 Voltage variation $17,20 \mathrm{~V}$

\begin{tabular}{|c|c|c|}
\hline NO & TIME & CURRENT \\
\hline 1 & 10 menit & $3,33 \mathrm{~A}$ \\
\hline 2 & 20 menit & $3,63 \mathrm{~A}$ \\
\hline 3 & 30 menit & $3,23 \mathrm{~A}$ \\
\hline 4 & 40 menit & $2,61 \mathrm{~A}$ \\
\hline 5 & 50 menit & $1,91 \mathrm{~A}$ \\
\hline
\end{tabular}

\section{c. Long time to Charging Accumulator}

Testing the length of time to charge the accumulator is determined by the amperage flowing toward the load. In this test the author uses a $12 \mathrm{~V}$ $3.5 \mathrm{Ah}$ accumulator consisting of 6 cells, the voltage limit for one cell is $2.22 \mathrm{~V}-2.33 \mathrm{~V}$. So the actual voltage $12 \mathrm{~V}$ accumulator is between $13.3 \mathrm{~V}-13.9 \mathrm{~V}$. Lever recommended accumulator charging up to a voltage of $1.75 \mathrm{~V}$ per cell. Sehinnga said that the accumulator needs to be charged at a voltage of 10.5 $\mathrm{V}$. The following is a table of the results of the accumulator charging time at the initial charger voltage of $13.88 \mathrm{~V}$ and the final voltage of $13.4 \mathrm{~V}$.

Tabel 7 Time to charge the Acumulator

\begin{tabular}{|c|c|c|c|c|}
\hline NO & $\begin{array}{c}\text { TEST } \\
\text { NO. }\end{array}$ & $\begin{array}{c}\text { START. } \\
\text { VOLT }\end{array}$ & $\begin{array}{c}\text { FINAL } \\
\text { VOLT }\end{array}$ & $\begin{array}{c}\text { CHARGING } \\
\text { TIME }\end{array}$ \\
\hline $\mathbf{1}$ & 1 & $10,5 \mathrm{~V}$ & $13,4 \mathrm{~V}$ & 02.11 .33 \\
\hline $\mathbf{2}$ & 2 & $10,5 \mathrm{~V}$ & $13,4 \mathrm{~V}$ & 02.11 .05 \\
\hline $\mathbf{3}$ & 3 & $10,5 \mathrm{~V}$ & $13,4 \mathrm{~V}$ & 02.10 .35 \\
\hline $\mathbf{4}$ & 4 & $10,5 \mathrm{~V}$ & $13,4 \mathrm{~V}$ & 02.12 .55 \\
\hline
\end{tabular}

In the second experiment with a voltage variation of $13.88 \mathrm{~V}$, the results are presented in table 3 as follows. a. The voltage variation test is a test carried out on the transformer output. The voltage variation was carried out on the transformer with an initial voltage of $10 \mathrm{~V}$ and then a charging voltage of $12.70 \mathrm{~V} ; 13.88 \mathrm{~V} ; 14.27$ $\mathrm{V} ; 15.14 \mathrm{~V}$; and 17.20 V DC and gives the same length of time. The following are the results obtained

b. A good output voltage output in charging the accumulator by considering several factors and setting the voltage at $13.88 \mathrm{~V}$.

c. The length of time it takes to charge the accumulator with a good voltage.

\section{RESULTS AND DISCUSSION}

This research was conducted with 3 stages of testing. The first stage is to test the output of the transformer which produces a voltage of $12.70 \mathrm{~V} ; 13.88 \mathrm{~V} ; 14.27$ $\mathrm{V} ; 15.14 \mathrm{~V}$ and $17,20 \mathrm{~V}$. The second stage is testing the variation of the charging voltage to the accumulator with an initial voltage of $10 \mathrm{~V}$ and charging for various voltage variations, namely; $12.70 \mathrm{~V} ; 13.88 \mathrm{~V} ; 14.27 \mathrm{~V} ; 15.14 \mathrm{~V}$; and $17,20 \mathrm{~V}$. The third stage of testing the length of time to charge the accumulator is determined by the amperage flowing to the load

a. The result of the design between the automatic smart charging control system and the Arduino Uno microcontroller.

b. A good output voltage output in charging the accumulator by considering several factors and setting the voltage at $13.88 \mathrm{~V}$.

c. The length of time it takes to charge the accumulator with a good voltage.

Discussion

In this discussion, the author will discuss the test results on the product design and the results of the analysis that has been carried out. From the test results on each component of the smart charging device, the results are in accordance with expectations, which is designed to be tough, smart, and as efficient as possible..

In the discussion of the results of voltage variations, different values of current are obtained, each time the voltage is entered from tap 1 to tap 6, the voltage that comes out on the smart charging device is getting bigger. In this case, it will affect the current flowing to the accumulator. This can be seen in the results of the six graphs where the current flowing is greater the greater the input voltage. With the results obtained from the presentation of data and analysis results, the authors use a voltage of $13.88 \mathrm{~V}$ in the operation of the tool automatically because at 
this voltage the output flows an average current of 0.9 A per hour. In the experiment, charging the accumulator with a capacity of 3.5 Ah with a large current of $0.9 \mathrm{~A}$, it will take approximately 4 hours. This time is considered sufficient and the amperage that flows is also stable, so that the accumulator that is being charged is not hot and is not easily damaged. The charging operation does not choose another voltage, because it takes into account various factors ranging from charging time to things that can cause the charged accumulator to become damaged.

The process of charging the accumulator takes different times, depending on the accumulator voltage to be charged. In a series of experiments carried out in table 4.8. The accumulator that will be charged is set at a voltage of $10.5 \mathrm{~V}$ (the lowest voltage) because this voltage can be said to be at the charging level. The accumulator voltage is said to be full when it reaches a voltage of 13.4 V. From the results obtained, the accumulator filling time at a voltage of $10.5 \mathrm{~V}$, the average time needed is about 2 hours, 11 minutes, 32 seconds.

\section{CONCLUSION}

Based on the design and testing that has been done, it can be concluded that Arduino Uno is a simple minimum system that can be used for various control purposes, Sensor reading - the sensor is directly proportional to the sensor output voltage, based on the tests that have been carried out, the design can run well and can be applied as a smart charging digital. From the test results, errors are due to the sensitivity of sensors.

\section{ACKNOWLEDGMENT}

The researcher thanked to the Head of Electrical Engineering Study Program and the Dean of the Technical Faculty of PGRI Adi Buana Surabaya University who had provided facilities in this research process.

\section{REFERENCE}

[1] Abdul kadir dan Terra Ch, Triwahyuni, 2010 Pengenalan Teknologi Informasi, Yogyakarta, penerbit Andi

[2] Andri, Helly, 2010. Rancang Bangun System Battery Charging Automatic, Universitas Indonesia

[3] Ika Wulandari, Triyas, 2010 Rancang Bangun Sistem Penggerak Pintu Air Dengan
Memanfaatkan Energi Alternatif Matahari, Institut Teknologi Sepuluh November

[4] Istiyanto, J. E. (2014). Pengantar Elektronika dan Instrumentasi Pendekatan Project Arduino dan Android. (T. A. Prabawati, Ed.). Yogyakarta: ANDI

[5] Kadir, Abdul. 2014, Panduan Praktis Mempelajari Aplikasi Mikrokontroler dan Pemrogramannya menggunakan Arduino. Yogyakarta : Penerbit Andi diakses pada tanggal 28 oktober 2019

[6] Kho, Dickson. 2019. Prinsip Kerja DC Power Supply. Retrieved from: https://teknikelektronika.com/prinsip-kerja-dcpower-supply-adaptor/ diakses pada tanggal $11 / 01 / 2020$

[7] Marpaung, May Harpri Rabiman. 2014. Monitoring Suhu dengan Menggunakan Sensor Suhu LM35 Serta Pengaturan Suhu Pada Otomatisasi Dispenser Berbasis Arduino UNO dengan Tampilan LCD. Tugas Akhir. Universitas Diponegoro

[8] Mubaraq, Husni. 2017. Alat Pengisian Aki Bebasis Mikrokontroler. Skripsi. Padang: Elektro politeknik Negri Padang

[9] S.N. Khalid, M.W. Mustafa H Shareef, M. Mustapha I. Abubakar, Calibration Of ZMPT101B Voltage Sensor Module Regression For Accurate Load Monitoring, 2006

[10] Syahwil. 2013 Teknik Pemrograman Arduino Sederhana. Surabaya: Gramedia 